ABSTRACT: This article reads Thomas Hardy's The Woodlanders (1887) and Jude the Obscure (1895) as ambivalent responses to the new conception of human intelligence which emerged from Victorian psychology and evolutionary theory and which formed the basis of what I describe as the Victorian biopolitics of intelligence. Although these novels reflect Hardy's endorsement of the new biological model of intelligence, they also register his resistance to what many late Victorians assumed to be its corollary: that mental worth can be an object of scientific measurement, classification, and ranking. I suggest that the work of the philosopher Jacques Rancière illuminates the extent to which these novels challenge the scientific reification of intellectual inequality and attempt to vindicate overlooked and stigmatised forms of intelligence.

Thomas Hardy and the Value of Brains

Sara Lyons

In one of the most celebrated passages in Thomas Hardy's oeuvre, Henry Knight, the rationalist hero of A Pair of Blue Eyes (1873), has a dramatic reckoning with the implications of Darwinian science and deep geological time. Dangling off the face of a cliff, he realises he is eye to eye with a trilobite fossil, and this prompts him to contemplate his own mortality and the fragility of civilisation as if they were equivalent. Knight readily perceives himself as an incarnation of humanist ideals, and so understands the "dignity of man" (209) to be at stake in his predicament - a presumption that Hardy ironises but also encourages us to take seriously, at least insofar as we are asked to read the situation as an allegory of humanism in crisis. Throughout the scene, Hardy emphasises that the evolutionary perspective on humanity is humiliating for a man like Knight: he is distressed not simply by an atheistic sense of death's finality, but by the idea that he will be "with the small in his death" ([emphasis mine], 209). This formulation is odd but precisely revealing. Knight experiences his animal status as a catastrophic form of downward mobility — the trilobite is like an "underling" (209) who has the temerity to address him on terms of equality, and he imagines he will somehow continue to feel degraded by their intimacy even when he too is a fossil. In this state of extreme physical vulnerability, we might expect Knight to invest little value in 
his mental capacities. In fact, his abjection makes his sense of intellectual superiority all the more potent:

Most men who have brains know it, and few are so foolish as to disguise this fact from themselves or others, even though an ostentatious display may be called selfconceit. Knight, without showing it much, knew that his intellect was above the average. And he thought — he could not help thinking — that his death would be a deliberate loss to earth of good material; that such an experiment in killing might have been practised upon some less developed life. (212)

Knight's sense of having been reduced to the same level as a trilobite, a form of "intelligence [un]worthy of the name" (209), paradoxically intensifies his sense of his high place within an exclusively human hierarchy of "brains". Yet this hierarchy is not really an alternative system of value. Knight appraises his own intelligence in evolutionary and thoroughly materialist terms: it is precious not because it constitutes a moral or spiritual dimension to his nature, nor even because it will deliver concrete benefits to humanity (Knight is a critic and something of a dilettante) but because it is "good material", more worth preserving than other "less developed" forms of life. Hardy here allegorises not only the high Victorian struggle to "find a scale for the human" in the vastness of Darwinian evolution, but also anticipates how that struggle would generate eugenicist modes of logic in the final decades of the century. ${ }^{\mathrm{i}}$

Strikingly, Knight finds the eugenicist perspective on his death consoling: it restores some of the pride that evolutionary thinking has cost him. Likewise, he appears to find it gratifying to conceptualise himself in statistical terms: his death will be especially regrettable because his brains are "above average". Although Hardy encourages us to pardon Knight for 
being conscious of his mental gifts, he suggests there is something transgressive in Knight's train of thought when he writes that Knight "could not help thinking" of his death as an exceptional tragedy. There is a troubling vagueness to the phrase "some less developed life": does Knight simply think it would be better if a "zoophyte", "mollusc" or "shell-fish" died in his place (209), or also that it would be better if a human being of lesser intelligence did? And better according to what calculus? Although I have described Knight's logic as "eugenicist", its ultimate rationale is unclear: the "earth" itself seems to the only potential loser or beneficiary in relation to his survival. "Earth" arguably suggests "humanity" in this context, but Hardy's choice of this word is surely deliberate, since it is able to convey materiality and abstraction at once: it implies that Knight, having come to understand his own intelligence in scientific terms, cannot see what meaning it might have except as organic matter, or in relation to planetary processes.

Knight's evaluation of his own brains on the cliff face in A Pair of Blue Eyes reflects Hardy's sensitivity to the implications of the new conception of human intelligence that was first theorised in the works of mid-Victorian psychologists, most notably Herbert Spencer, and which would eventually culminate in the rise of intelligence testing and the notion of IQ (Danziger, 69-74). In Spencer's work, “intelligence” is purged of any spiritual or humanist value; it is a thoroughly biological category, and even the most sophisticated of intellectual achievements are on a continuum with animal instinct. "Intelligence" refers not to any special human aptitude for reason, still less to any moral or spiritual quality, but to the basic processes by which organisms adapt themselves more or less successfully to their environments (Spencer, Principles of Psychology 388-426). This novel definition of intelligence became central to Darwin's theory of evolution by natural selection as well as to the eugenicist thought of Francis Galton and his followers. As Kurt Danziger points out, the erosion of the distinction between human and animal intelligence galvanised a cultural 
obsession with establishing the different degrees of intelligence possessed by individuals and groups and with articulating how these differences related to hierarchies of gender, class, and race. The potentially egalitarian collapse of distinctions between mind and body, reason and instinct, and human and animal instead "sanctified ancient chasms between different types of humans" and ushered in an unprecedented drive to measure, classify, and rank the "gradations" of mental capacity (Danziger, 70).

The roots of the intelligence test and the associated concept of meritocracy in nineteenth-century eugenics and Social Darwinism, particularly in the work of Galton and Spencer, are generally acknowledged in histories of these phenomena. ${ }^{\text {ii }}$ However, the extent to which intelligence became a biopolitical concern in Victorian Britain is not widely recognised. In Michel Foucault's work, "biopolitics" refers to a transformation of political power which took place in the nineteenth century as states attempted to harness the insights of the life sciences and thereby take control of the biological. In place of the old sovereign right "to take life and let live", states now assumed the prerogative to "make live and to let die": that is, to nurture and regulate the health of the social body (Sexuality 135-6). Foucault suggests that biopower emerges both through and alongside the forms of disciplinary power which he analysed in Discipline and Punish (1975). Where disciplinary power aims to render individual bodies useful and docile through techniques such as training and surveillance, biopower "deals with the population as a political problem, as a problem that is at once scientific and political" (Society 245). It is characterised by efforts to measure and intervene in processes such as birth, death, reproduction, and disease as they play out at the level of the collective. The population is turned into a calculable, governable object through methods such as demography and statistics, and the individual is subsumed under the abstract imperatives of the "species", or biological health in the aggregate (Society 242). Foucault closely identifies biopolitics with state racism, which he characterises as an impulse to 
fragment and stratify the human species into superior and inferior "races", or "healthy" and "degenerate" bodies - a logic which he suggests its reached its twentieth-century apogee in Nazi eugenics (Society 254-257). However, he also emphasises the more subtle or benign manifestations of biopower in capitalist processes and state welfare systems, and claims that its characteristic modus operandi is not through laws or violent force but through the pressure of norms (Sexuality 141 and Society 250-251). A biopolitical society is a "normalising society", one in which institutions and social discourses "measure, appraise, and hierarchise" around norms and which incites people to internalise and perpetuate norms for themselves (Sexuality 144).

Although Foucault remarks in passing that biopolitics is concerned with optimising the "aptitudes" of the population, he does not consider the fact that intelligence had been transformed into measurable, biological entity in the nineteenth century (Sexuality 141). Ansgar Allen has recently suggested how the notion of biopower illuminates the assumptions about mental capacity circulating within the state education system which evolved in Britain following the Education Act of 1870. In particular, Allen highlights the disturbing continuities between Galton's eugenicist model of intelligence and the rationality and practices of the state school system, especially in its reliance on examinations (97-125, 136250). Over the course of the nineteenth century, the formal written exam and procedures of grading and ranking pioneered at Oxford and Cambridge universities in the eighteenth century came to dominate academic life at those institutions while also migrating to other contexts, most notably the Civil Service and the expanding mass education system and its "scholarship ladder". iii As Gillian Sutherland and Simon Szreter have shown, Victorian examination culture generated a desire to distinguish between natural ability and acquired knowledge, and this in turn helped to crystallise the IQ concept: that is, the notion of intelligence as a general, innate quality which can be objectively captured by exams 
(Sutherland, 97-127 and Szreter, 160-173).

Galton's fascination with the capacity of exams to sort and rank people on a mass scale directly led to his efforts to construe intelligence in statistical terms (Galton, 6-7,19-35). Galton argued that intelligence levels within a population obey the statistical law of normal distribution, clustering densely around a norm and creating the familiar bell-shaped curve on a graph: nature predictably yields a preponderance of mediocrities, a relatively small cognitive elite, and a relatively small class of "idiots and imbeciles" (Galton, 26-36). Galton was also responsible for popularising the notion of intelligence as a unitary, heritable trait, largely impervious to environmental influences. Although Galton was certainly the most zealous hard hereditarian of the period, his conviction that intelligence is determined by heredity was endorsed by Darwin and shared even by prominent psychologists and scientists who favoured a Lamarckian interpretation of evolution, such as Henry Maudsley, Théodule Ribot, and Spencer. ${ }^{\text {iv }}$ The new scientific discourses emphasising the essentially fixed, congenital nature of intelligence began to undermine the liberal faith in the primacy of education and individual agency in a person's social destiny. Such faith was closely associated with the work of John Stuart Mill and had underwritten optimistic cultural narratives of social mobility in the 1850s and 1860s (Paul and Day; Meroni, 46; White). By the early 1880s, however, there was a mounting cultural panic about the apparent prevalence of mental deficiency in the population, especially in relation to the lower-class children the state had committed to educating (Sutherland, 5-7). The supposed physiological limits and risks of education were widely discussed. There was a spate of government inquiries into the problem of "ineducable" children; doctors entered schools to perform physical tests on students and classify them as being above, below, or of average mental capacity (Sutherland, 5-24). Meanwhile, a chorus of scientists and intellectuals proclaimed that Darwinian evolution or modern understandings of heredity had revealed that the French and American 
revolutionary principle of "natural equality" was an abject fantasy: human inequality was a scientific fact, and it expressed itself most starkly in intellectual differences. ${ }^{\mathrm{v}}$ As T. H. Huxley put it, "proclaim human equality as loudly as you like, Witless will serve his brother" (10).

Hardy has often been understood as a melancholy student of late Victorian biological determinism, his magpie reading of contemporary science and psychology feeding his sense of the supremacy of the tragic in both art and life. ${ }^{\mathrm{vi}}$ Yet critical discussions of the significance of evolutionary and hereditarian thought in Hardy's work have not closely scrutinised how these shaped his understanding of intelligence, and for this reason, have often underestimated how strenuously he sought to think equality after Darwin. In what follows, I read Hardy's The Woodlanders (1887) and Jude the Obscure (1895) through the prism of Jacques Rancière's efforts to theorise intellectual equality and the politics of the nineteenth-century novel. ${ }^{\text {vii }}$ Rancière work celebrates and attempts to think through the extent to which democratic politics entail the "mad presupposition that everyone is intelligent as anyone else" (Consensual Times 2). This is also the provocation at the centre of his book, The Ignorant Schoolmaster (1987), which recuperates the theories of the Romantic pedagogue Joseph Jacotot in order to critique modern conceptions of intelligence and education. In other parts of his work, Rancière has made bold claims for the radically egalitarian character of the nineteenth-century novel. He defines the novel as a "genre without genre" (Flesh of Words 92) which shatters the hierarchical protocols of classical literature and takes for its subject anyone and anything at all. In his view, the egalitarianism of the form is independent of the political beliefs of any given novelist and distinct from explicitly political campaigns for democracy or social emancipation. "Literary democracy" inheres in the propensity of the novel to honour the capacity of "anyone whomsoever [to] experience any emotion or passion whatsoever" (Lost Thread 14). He goes on: 
This new capacity of anyone at all to live any life at all ruins the model linking the organicity of the story to the separation between active and passive men, elite and vulgar souls. It produces this new real, $[\ldots$ which is] the interlacing of a multiplicity of individual experiences, the lived fabric of a world in which it is no longer possible to distinguish between the great souls who think, feel, dream and act and individuals locked in the repetition of bare life. (Lost Thread 15)

The Woodlanders and Jude are pervaded by and in some ways complicit in the late Victorian biopolitics of intelligence. Yet they are also concerned to reveal how the intelligence of both major and minor characters exceeds their social positions and eludes modern efforts to measure and rationalise mental capacity. These novels counter the scientific reification of intellectual inequality in various ways: by making an egalitarian poetry out of the interrelations between and amongst human beings and non-human nature, a strategy prominent in The Woodlanders; by insisting upon the fundamentally political and contestable nature of judgments about mental worth, a strategy apparent in both novels; and by positing extreme suffering as the authentic ground of intellectual value, a strategy favoured in Jude.

\section{The Value of Brains in The Woodlanders}

In The Woodlanders, Hardy's interest in mental measurement is encapsulated in the subplot involving a minor rustic character, the servant woman Grammer Oliver. The gentleman scientist Edred Fitzpiers contracts to procure Grammer Oliver's brain upon her death, so that he may dissect it and probe the mystery of its freakish, masculine size. Grammer Oliver's peasant materialism initially appears compatible with Fitzpiers' interest in craniometry - 
that is, the measurement of skulls and their contents — but her bargain soon comes to feel Faustian to her: she worries that the brain she was happy to treat as a commodity and scientific specimen may in fact be the locus of her soul (46). In context, the Grammer Oliver episode resonates as a comic allegory of the novel's wider concern with how the forces of modernity collide with folk traditions in rural England. Yet Grammer Oliver's belated qualms about her soul attest not merely to the tenacity of supernatural belief among the peasantry. The fact Grammer Oliver sells her brain ostensibly to science but more truly to gratify the whim of a bored aristocrat makes the transaction appear akin to prostitution, or a peculiarly macabre droit de seigneur. Fitzpiers' attempt to acquire Grammer's brain is clearly intended to parallel his seduction and marriage of the novel's heroine, Grace Melbury; in both cases, a lower-class woman piques the interest of an aristocratic man of science on account of the exceptional nature of her mind. Fitzpiers treats both women as objects of scientific curiosity and collection, and this establishes an imaginative link between the mental refinements Grace has attained through education and Grammer's "fine brain" (109). The parallel in turn sets up the question of whether intelligence is primarily inborn or acquired, even as it is foregrounds the distorting effects of Fitzpiers' power relationships with both women upon his capacity to arbitrate what Galton had recently christened the "nature/nurture" distinction. ${ }^{\text {viii }}$

As Stephen Jay Gould has argued, the late nineteenth-century enthusiasm for craniometry was the direct precursor to the rise of intelligence testing at the century's close. Interest in measuring skulls was driven by the misconception that skull and brain size are reliable indices of intelligence, and the practice was central to the efforts of nineteenthcentury anthropologists to establish the intellectual inferiority of non-European peoples (Gould, 62-173). It motivated the accumulation of vast private and public collections of human skulls, since large numbers of measurements were needed to place the study of racialised mental difference on an "objective" footing and render it amenable to statistical 
analysis. One of the most prominent exponents of the technique, the French anatomist Paul Broca, also believed that it could prove the intellectual inferiority of women and the lower classes — an assumption implicit in Fitzpiers' curiosity about the size of Grammer Oliver's brain (Gould, 127-141). Craniometry was among the methods Galton used to measure intelligence in the laboratory he set up in London in 1884, and it was part of his research at the University of Cambridge in 1885, where he sought to correlate the exam results of students with their skull measurements (Gould 108; Venn).

Fitzpiers' interest in craniometry marks him out as a kind of anthropologist in Little Hintock; he studies the "natives" and attempts to collect skulls and brain specimens with a presumption of intellectual detachment, though Hardy makes clear he is in fact driven by his narcissism and libido. Jane Bownas aptly identifies Fitzpiers' assumptions as an illustration of the logic of "internal colonialism" (5, 105-112): as Foucault observed, the techniques of domination that European powers deployed against colonial populations often resurfaced as means of controlling domestic populations (Society 103). Indeed, Fitzpiers appears to conceive of himself as a kind of colonial administrator: he arrives determined to "inaugurate a new era" of "advanced ideas and practices" and shows a lofty disdain for established beliefs, while treating the local women as his sexual chattel $(93,46)$. The villagers regard Fitzpiers as a kind of necromancer, and Hardy asks us to see that are some grains of truth in this perception, at least insofar as his scientific research has a pronounced mystical bent. More precisely, Fitzpiers' science is informed by his idealist metaphysics, and such metaphysics are in his case a monstrous form of magical thinking, a refusal to believe in the existence of a world beyond his own desires (118). Hardy discredits Fitzpiers' investment in measuring minds both morally and epistemologically: it represents not an authentic curiosity about the nature of other minds, but a wish to at once possess and negate the reality of others. Significantly, Hardy grants Grammar Oliver herself the prerogative of critiquing 
the theory of intelligence implicit in Fitzpiers' interest in craniometry. Grace enquires: "Was [Fitzpiers] really made for higher things? Is he clever?” (45). Grammar Oliver replies, "Well no. How can he be clever? [...] These young men — they should live to my time of life, and then they'd see how clever they were at five and twenty!" (45). There is a neatly ironic chiasmus here. For Grammar Oliver, apparently the superstitious rustic, intelligence is not a metaphysical given but thoroughly secular and empirical: it is acquired over time, through worldly experience. Meanwhile Fitzpiers, apparently the detached scientist, is possessed by the desire to fathom metaphysical essences, and "scarcely able to distinguish between reality from fancy" (118). Fitzpiers' dual identity as aristocrat and scientist underscores the power of the modern sciences of mental measurement to legitimise ancient class distinctions. Likewise, Fitzpiers' self-serving amalgam of idealism and materialism calls attention to the capacity of science to be pressed into the service of ideology. Rancière suggests that the insidious power of the idea of intellectual inequality lies partly in the fact that its exponents justify it on spiritual or material grounds according to convenience:

The superior minds want neither a superiority that would be only material nor a spirituality that would make them the equals of their inferiors. They lay claim to the differences of materialists in the midst of the elevation that belongs to immateriality. They paint the cranioscopist's skulls with the innate gifts of intelligence. (Ignorant Schoolmaster 48).

This is true of Fitzpiers, whose sense of superiority is so absolute that it leads him to suggest to Grace that he belongs to a different "tribe" or "species" (161) to the laboring classes but who is nonetheless uncertain about whether that superiority is a gift of birth or education: 
"I dare say I am inhuman, and supercilious, and contemptibly proud of my poor old ramshackle family; but I do honestly confess to you that I feel as if I belonged to a different species from the people who are working in that yard." "And from me too, then. For my blood is no better than theirs."

[...] It was, indeed, a startling anomaly that this woman of the tribe without should be standing there beside him as his wife $[\ldots]$

"Ah YOU_-you are refined and educated into something quite different," he said, self-assuringly. (161-2)

Fitzpiers is primarily eager to establish that there are, in Rancière's terms, "two humanities", one in possession of an "active intellectual faculty" and capable of refined thoughts and grand actions, the other consigned to the realm of "passive materiality" (Rancière, Discontents 31-32). When Grace protests that she falls on the wrong side of the "species" division Fitzpiers imagines, it is easy enough for him to reconfigure its terms, since whether the ground of the division is biology or education matters less than the maintenance of the division itself.

Hardy makes clear that Fitzpiers' craniometry is a less a science than a form of occultism that invests unequal social relations with mystical authority. This perception is reinforced by the parallel Hardy establishes between craniometry and phrenology. Grace's father is confident that she constitutes worthwhile "material" (140) for an education because he has consulted phrenologists on the matter: "Her fortune has been told by men of science — what do you call 'em — phrenologists" (70). As Hardy's characterisation of it as form of fortune-telling suggests, phrenology had lost much of its scientific credibility by the second half of the nineteenth century, but it led a busy afterlife as form of popular entertainment and 
folklore. In identifying phrenology with Mr. Melbury, the ambitious provincial merchant, and craniometry with Fitzpiers, the mystical amateur scientist, Hardy charts quite precisely the development of the science of mental measurement in the nineteenth century. Craniometry was sometimes called the "new phrenology" because it promised to succeed where phrenology had failed and decipher the secret correspondence between mental and physical characteristics (Wilson). However, by the fin de siècle, scientific confidence in craniometry, particularly in its capacity to determine intelligence, was also receding (Dickey 213-222). In The Woodlanders, the dubiousness of both methods of ascertaining mental worth is underscored by the acquisitive motives of the men who subscribe to them. Mr. Melbury's naive faith that phrenology has proven his daughter's natural aptitude for education is matched by his naive and mercenary conception of education itself: "You can't teach her anything new. She's been too far among the wise ones to be astonished at anything she can hear among us folk in Hintock" (70). Mr. Melbury fetishises education because he imagines that it confers a static, incontrovertible form of social power. In his fantasy, education is not a process but a property with a fixed value. This logic obviously turns education into a sterile, self-negating enterprise, the opposite of the humanist ideal of bildung: one gains an education so that one never has to learn anything new, nor ever be surprised.

In a quieter way, The Woodlanders articulates a disenchantment with formal education as complete as we find in Jude. And like that novel, The Woodlanders is a kind of nihilistic bildungsroman: Grace gains an education only to realise there was nothing worth learning; the truly valuable knowledge is the rustic wisdom she grew up among in Little Hintock, and the effort to extend beyond it is only self-betrayal and destruction. Hardy's pessimism about education and social mobility in his last novels can seem perverse given that opportunities for both were expanding toward the end of the century. Nevertheless, as Jane Mattisson has detailed, Hardy's insistence upon the class-bound nature of the education 
system accurately reflects the elusiveness of such opportunities as well as the elitist effects of meritocratic reform, which overwhelmingly favoured upper- and middle-class men (51-101). Beyond this, Hardy's jaundiced view of education needs to be understood in the context of the rise of scientific discourses of innate intelligence, which, taken to their extreme conclusion, could make education seem a superficial, largely diagnostic process, capable of measuring and classifying but not of substantially improving a person's mind. It is this essentialist and deterministic understanding of intelligence that partly accounts for the stagnant nature of Grace's bildung plot — that is, the failure of her education to produce any significant moral or intellectual development — as well as the motif of blighted growth that runs throughout the novel. For as the rest of the novel makes clear, the allegory of class and gender domination encoded in Fitzpiers' purchase of Grammer Oliver's brain applies equally to Grace: her brain, no less than Grammer Oliver's, is subject to the logic of reification, both in the sense that it is a commodity to be bought and sold by men, and in the sense that her intelligence is conceptualised by men as essentially fixed natural endowment, only somewhat "refined" (162) or "finished" (140) by education.

Although Mr. Melbury boasts of his Grace's natural fitness for education, it is important the novel never straightforwardly vindicates his paternal pride, and indeed does much to suggest that it is misplaced. The fact that Grace's supposed mental superiority is primarily registered in the class-conscious, reifying discourses of her father and Fitzpiers casts doubt on its reality; for much of the novel, it seems to signify nothing more than "a veneer of artificiality" (186). When Grace is disillusioned by Fitzpiers, she becomes an avid reader, and this turn toward books seems to mark the beginning of a morally serious form of self-cultivation, in contrast to the spurious kind she acquired at school (309). Yet Grace remains a curiously flat, superficial character; Hardy never endows her with the kind of vibrant inner life we would expect of a bildung progatonist (nor indeed of a Hardy heroine: 
Hardy himself apparently struggled to invest her with imaginative energy, considering her "too commonplace and straitlaced" to be capable of real passion or worthy of a "fine tragic ending" [Qtd. Dutta 88]). At the novel's end, Hardy reduces Grace's interiority to a homily: she comes to learn "how little accomplishments and culture weigh beside sterling personal character" (301). Hardy even limits the extent to which Grace is permitted to gain tragic depth in the aftermath of her moral awakening, since it leads only to further compromise: after Giles Winterborne has sacrificed his life for her, she reconciles herself to a debased marriage with Fitzpiers, and the grandeur and pathos of the novel's tragic conclusion is instead conferred upon the peasant girl who loved Giles unrequitedly, Marty South.

On the most obvious level, this aggrandisement of the novel's rustic characters at the expense of their educated counterparts reaffirms old moralistic understandings of the intellect. As Lorraine Daston notes, the Victorian psychologists and scientists never fully succeeded in detaching the category of "intelligence" from its freight of moral and religious meanings (212). Such meanings are woven into the romance fabric of The Woodlanders: Fitzpiers'sophistication marks him out as a devil or Faust archetype, while Giles' simplicity reflects his status a Green Man/Christ figure; Grace's education is the cause of her fall into class consciousness and treachery to Giles, whereas Marty the peasant girl is defined by her sublime fidelity to him. Yet the novel's engagement with the new scientific conception of intelligence goes beyond simple moral rejection. It is in fact Hardy's endorsement of a thoroughly biological and evolutionary model of intelligence that underpins both the novel's egalitarian politics and its moral vision.

Throughout The Woodlanders, Hardy contests the idea that social class is a simple emanation of mental worth. This ancient prejudice had gained fresh prestige from Galton's eugenics as well as from Spencer's Social Darwinism, both of which suggested that social hierarchies reflect underlying biological differences, and that social position is a relatively 
transparent signifier of intelligence. The Woodlanders contests this assumption at the basic level of plot: the narrative springs from George and Grace Melbury's failure to distinguish between social position and inner qualities. Crucially, this is not simply a failure to hold Giles's moral goodness at its proper value; it is a failure to recognise the profundity of his intelligence. Where Hardy ironises the highly abstract and mystical nature of Fitzpiers' intellectual pursuits, he emphasises the embodied intelligence entailed by Giles' agricultural work. Fitzpiers' intellectuality is a form of solipsism that renders him not just morally callous, but stupid about basic empirical realities — a fact symbolised by the episode where he mounts the wrong horse, drifts asleep while riding, falls on his head, and then drunkenly reveals his sexual infidelities to Grace's father. Fitzpiers' desire to abstract himself from the natural world through "transcendental philosophy" (119) renders him much more vulnerable to bodily, instinctual impulses than Giles, whose acceptance of his interconnection with nature enables him to transcend such impulses - a paradox captured at the novel's close when he dies exposed to the elements rather than give way to sexual temptation with Grace. In this way, the novel schematically inverts the values conventionally ascribed to physical and mental labor, lower- and upper-class men: where Giles exemplifies introspection and "scrupulous delicacy" (282), Fitzpiers is prey to his grossest instincts and appetites.

Hardy's emphasis upon the "intelligen[ce]" manifested in Giles' "intercourse with nature" (297) extends to Marty too. It is in relation to her that the novel makes its most explicit statement about the arbitrariness of social class:

As with so many right hands born to manual labor, there was nothing in its fundamental shape to bear out the physiological conventionalism that gradations of birth show themselves primarily in the form of this member. Nothing but a cast of die of Destiny had decided that the girl should handle the tool; and the fingers which 
clasped the heavy ash haft might have skilfully guided the pencil or swept the string, had they only been set to do it in good time. (10)

The purpose of this passage is to establish Marty’s natural equality with Grace, not to lament that Marty has been denied opportunities for more refined occupations: as the rest of the novel makes clear, education and social mobility are at best mixed blessings. Grace's failure to appreciate Giles' love until too late is duplicated in Giles' failure to hold Marty's love at its proper value, and the pathos of this latter tragedy is amplified by the fact that it is repeated at the level of the novel's distribution of narrative attention. As Alex Woloch has argued, nineteenth-century novels often register the pressures of expanding democracy and social inequality by problematising the distinction between major and minor characters and the relative narrative attention accorded to each (30-32). In the case of The Woodlanders, Hardy encourages us to regret that Grace, rather than Marty, is the novel's heroine, or at least to recognise that Marty has equal claim upon the role. The wistful passage quoted above serves to underscore that Grace's status as heroine is as arbitrary as her acquisition of education and social mobility; she does not possess any particular mental qualities that elevate her above Marty. The fact that the novel's conclusion focuses on the tragedy of Marty's unrequited love and she utters the novel's final words further underscores her status not only as Giles' might-have-been wife but as the novel's might-have-been heroine.

In its focus on the overlooked intelligence of Marty and Giles, The Woodlanders disrupts what Rancière calls the "police" distribution of the sensible — that is, the hierarchical, totalising account of society which presumes that a person's intellectual capacity is aligned with his or her social identity and which prescribes what a person is able to feel, say, and do. In his efforts to make Marty's and Giles's intelligence perceptible, Hardy enacts, in Rancière's terms, a "count of the uncounted" — he "spoils the fit between bodies and 
meanings" and thereby exposes the contingency of the police order (Politics, 41). The confidence with which Hardy undermines distinctions between mental and physical labor, intellect and instinct in The Woodlanders is surely drawn in part from his reading of Darwin and Spencer. ${ }^{\text {ix }}$ In The Principles of Psychology (1855), Spencer argued that "the commonly assumed hiatus between Reason and Instinct has no existence [...] The growth of intelligence is throughout determined by the repetition of experience" (454). Darwin famously contends that much of what appears merely instinctual in animals can in fact be considered a form of reason, and that human reason must be understood as an adaptive development from such rudimentary acts (Darwin 2004, 86). However, where in Darwin and Spencer this perception of the organic, adaptive nature of intelligence sharpens the significance of the relative amounts of it possessed by individuals and groups (Danziger 68-71), Hardy uses it in The Woodlanders to challenge the legitimacy of conventional social judgments about mental capacities. In particular, the novel refutes what Rancière calls the "opposition between the golden race and the iron race, any hierarchy — even an inverted one — between men devoted to manual work and men destined to the exercise of thought" (Ignorant Schoolmaster 37). Ventriloquising Jacotot, Rancière emphasises that intellectual emancipation consists not in "opposing manual knowledge, the knowledge of the people, the intelligence of the tool to the science of schools or the rhetoric of the elite", but in recognising that there

are not two levels of intelligence, that any human work of art is the practice of the same intellectual potential. In all cases, it is a question of observing, comparing, and combining, of making and noticing how one has done it [...] The fabrication of clouds is a human work of art that demands as much — neither more nor less — labor and intellectual attention as the fabrication of shoes or locks. (Ignorant Schoolmaster 367) 
Hardy's loving attention to the particulars of Marty's manual labor leads us to feel that her work cannot be understood as a mere waste of her mental capacities, harsh and socially degrading though it may be. Describing her making spars for thatching, Hardy highlights that her labor is mental as well as physical, demanding not just "dexterous" hands but "critical” attention (9). Similarly, Hardy emphasises that Giles' and Marty's knowledge of the woodlands constitutes a sophisticated form of expertise. Where the novel deflates Fitzpiers' pretensions to esoteric knowledge, it suggests that Giles's and Marty have authentically deep insight into the nature of things - a kind of literacy in the language of the woods. This is not because the novel romanticises instinctual, embodied wisdom at the expense of scientific knowledge; rather, it aims to break down such distinctions. Marty's and Giles' understanding of the woods is so profound that it appears instinctual and even magical to Grace, but it is in fact the product of patiently accumulated observation and experiment - a means of knowing that proceeds by the same principles as Fitzpiers' study of brain tissue:

The casual glimpses which the ordinary population bestowed upon that wondrous world of sap and leaves called the Hintock woods had been with these two, Giles and Marty, a clear gaze. They had been possessed of its finer mysteries as of commonplace knowledge; had been able to read its hieroglyphs as ordinary writing; to them the sights and sounds $[\ldots]$ which had to Grace a touch of the uncanny, and even the supernatural, were simple occurrences whose origin, continuance, and laws they foreknew [...] together they had, with the run of the years, mentally collected those remoter signs and symbols, which seen in few, were of runic obscurity, but all together made an alphabet. (297-8) 
The ecological vision articulated in passages such as this also offers a critique of the the late Victorian preoccupation with classifying and quantifying mental differences. As John Heaney argues, The Woodlanders marks a shift in Hardy's attitude toward Darwinian evolution (518). Key passages in Hardy's earlier novels, the cliff scene in A Pair of Blue Eyes perhaps most famous among them, depict evolutionary monism as a devastating blow to human dignity and happiness. However, in The Woodlanders, the collapse of the distinction between humanity and nature, while still clearly tragic, no longer resonates as a mere degradation or loss of meaning; instead, the novel finds nobility and enchantment in the thoroughly organic nature of the human. Most strikingly, the novel's characters are persistently likened to trees, and this analogy enables Hardy to cast the human desire for flourishing in lushly poetic terms, as a beautiful urge toward growth. William Cohen captures this aptly when he notes that the novel's characters are frequently imagined as "rooted, budding, leafy and abloom" (9). This is not to suggest that the Hardy retreats to a preDarwinian pastoralism; he is careful to emphasise that trees, no less than animals and humans, are engaged in a struggle for existence pervaded by conflict and waste. ${ }^{\mathrm{x}}$ Nonetheless, Hardy's insistence upon the "arboreality" of the human, to borrow Cohen's phrase, enables him to conduct an immanent critique of the hierarchical conception of human intelligence which emerged from Victorian physiological psychology and evolutionary theory (Cohen, 17). In The Woodlanders, the perception that human intelligence is a wholly natural phenomenon, subject to the same processes of adaptation as animal and plant life, does not serve to validate human forms of competition and hierarchy as it does in the writings of Spencer and Galton; rather, it serves to make human differences, particularly those entrenched by class, appear negligible, a narcissism of small differences. If human intelligence is produced by same adaptive processes as the growth of trees, what do mental 
variations between humans really signify? Fitzpiers' conviction that he belongs to a different "species" to the laboring classes is rendered absurd by the novel's ecological vision, which dwarfs human categories and distinctions.

The felicity of Hardy's analogies between humans and trees in The Woodlanders often hinges upon the idea of silviculture, and thereby highlights not only the naturalistic status of human beings but human agency in interaction with non-human nature. Crucially, the metaphor of silviculture underscores that humans have the power to tend or damage one another's natural development. Giles' empathic intelligence is symbolised by his "marvellous power of making trees grow" (58), while Fitzpiers' arrogance is evident in his destruction of the elm that John South fancies is linked to his mortality. We are invited to perceive the connection between Mr. Melbury's reification of his daughter's intelligence as a commodity on the marriage market and his business as a timber merchant. Fred Reid suggests that such silviculture metaphors derive from Hardy's reading of the "Individualism" chapter of John Stuart Mill's On Liberty (1859), in which Mill writes that human nature is "not a machine to be built after a model, and set to do exactly the work prescribed for it, but a tree, which requires to grow and develop itself on all sides, according to the tendency of the inward forces which make it a living thing" (Mill, 66; and Reid, 190). Mill was here drawing upon Wilhelm von Humboldt's organicist concept of bildung, and making a larger argument for an education system that would nurture individualism rather than conformity. Grace's experience of formal education has stifled any such holistic or personal mode of selfdevelopment: "Cultivation had so far advanced in the soil of Miss Melbury's mind as to lead her to talk of anything save of that she knew well, and had the greatest interest in developing: herself" (40). Yet a Romantic ideal of bildung persists at the level of the novel's arboreal imagery and metaphors, suggesting that a richer and more enlightened conception of human flourishing is imaginable even if the potentialities of Grace, Marty, and Giles have been 
tragically undercut. In its vision of human nature as a dynamic living thing, treelike in both its capacity for growth and its susceptibility to damage, The Woodlanders attempts to counter the reification of intelligence as a fixed, measurable entity. The novel is thus not a simple Romantic lament that "Nature has lost its soul to modern science", as Mary Jacobus has it (117). It is precisely in and through Hardy's acceptance of a biological and evolutionary understanding of intelligence that he is able to preserve a Romantic sense of the immeasurability of minds.

\section{2. 'I Have Understanding as Well as You': Intellectual Equality and Jude the}

\section{Obscure}

The title of Jude the Obscure when it first appeared in serial form was The Simpletons, but Hardy changed it when someone pointed out the similarity to Charles Read's 1874 novel The Simpleton (Marroni 163). At first glance, the original title evokes the thread of the novel which romanticises Jude Fawley and Sue Bridehead as visionary innocents, too idealistic to adapt themselves to the cruelties of society or nature. However, it also points to the novel's iconoclastic stance toward late Victorian concepts of intelligence and intellectual value. That Hardy meant "simpleton" to carry a dissident charge is also indicated by his subsequent choices of title: Hearts Insurgent and The Recalcitrants (Marroni 163). By the fin de siècle, there was a deepening tendency to biologise the problems of poverty and criminality, and a related preoccupation with the ubiquity of "feeble-mindedness" among the poor; as noted, concern focussed with particular intensity upon the poor children newly in receipt of state education. ${ }^{x i}$ In this context, Hardy's sense that his protagonists may be classified fluidly — if ironically — as "simpletons", "insurgents", or "recalcitrants" is suggestive: it reflects his desire to position his novel as an incendiary if in some ways ambiguous intervention in the 
contemporary politics of mental ability.

Although Marjorie Garber suggests that Jude is doomed by his "logocentric wistfulness" and fetishisation of literature, he initially feels a bitter enmity toward books (154). It is a book's power to inculcate a sense of mental inferiority that first provokes explicitly suicidal feelings in the child Jude. Despairing of his capacity to teach himself Greek and Latin from an old grammar book, he concludes:

There were no brains in his head equal to this business; and [...] he wished he had never seen a book, that he might never see another, that he had never been born. Somebody might have come along that way who [...] might have cheered him by saying that his notions were further advanced than those of his grammarian. But nobody did come, because nobody does; and under the crushing recognition of his gigantic error Jude continued to wish himself out of the world. (33)

Jude's contradictory status as at once the "quintessential biopolitical novel" and as a a lacerating critique of the late Victorian biopolitics of intelligence is submerged in this passage. ${ }^{\text {ii }}$ On the one hand, the novel invites us to interpret the young Jude's suicide ideation as a symptom of his degeneracy and "unfitness" for the disciplines of education and social advancement, a degeneracy which is inherited by Father Time, his suicidal/fratricidal son. ${ }^{\text {xii }}$ On the other, Jude's despair is also inseparable from the novel's political rage, which is directed at the class and religious ideologies which convince Jude of the inferiority of his brains. The novel bears witness to the truth of Rancière's assertion that "what stultifies the common people is not their lack of instruction, but the belief in the inferiority of their intelligence" (Ignorant Schoolmaster 39). Like The Woodlanders, Jude assails the idea that there are "two humanities" or "two levels of intelligence", but in Jude this is above all an 
indictment of what we are encouraged to understand as the Victorian class theology of intelligence, the division of the world into "thoughtful and mentally shining ones" (22) and the "despairing worthless" (71).

Rancière observes that the transformative encounter with a book is a stock novelistic trope which assumed a special place in nineteenth-century worker's literature. In such literature, the encounter with a book serves to allegorise how a child of the laboring classes is initiated into literacy and thereby into "another destiny" (Mute Speech 90). Rancière notes that the same topos also surfaces in reactionary form in novels produced by nineteenthcentury litterateurs alarmed by "the invasion of the temple of art" (Mute Speech 90). In the reactionary version, the working-class child's encounter with a book is the "work of death": the child is infected with impossible fantasies of social mobility and ultimately succumbs to criminality or despair, thereby illustrating the fatality of mass literacy (Mute Speech 90). Jude's suicidal misery over the grammar book is open to being read in this way: the discovery of the world of learning is for him not the start of a process of self-development but the seeds of self-destruction. However, Hardy's eagerness to demystify the labor involved in literacy circumvents the conservative cautionary-tale reading of Jude's intellectual ambition. The initiation scene dramatises not Jude's unfitness for education but instead clarifies how easily and early the intellect of a child may be stultified. The young Jude understands learning in quasi-supernatural terms, as a form of alchemy: in his "innocence", he fancies that there is a "law of transmutation" which enables Latin and Greek to be converted into English, and is demoralised when he realises that languages must be acquired at the cost of "years of plodding" (30). Jude takes the discovery that education is a form of labor as a symptom of his personal unworthiness, a reflection of his status as a member of the laboring classes (30). As the rest of the novel makes clear, however, this conception of education as a magical transmutation is far from being an "innocent" child's fancy; it is an ideology by which 
Victorian class inequality is maintained, and Jude remains enthralled by it as an adult. Jude imagines Oxford (called Christminster in the novel) as a city of celestial luminosity, and those who attend it as ethereal beings, "mentally shining ones"; although he becomes a conscientious autodidact, he remains tantalised by the notion that learning ought to be experienced as pure transcendence, not merely leisured but disembodied and out of time. Jude does come to recognise how his own labor, both imaginative and physical (he finds employment in Oxford as a stonemason), has served to fortify the illusion of a city devoted to pure spirit — an insight that the narrator calls a "true illumination" (84). But this enlightenment is only "moment[ary]"; Jude continues to "love" Oxford even when he recognises that it "hates all men like me" and despises the "labored acquisitions" of the "selftaught" (320). The real lesson of the grammar book — that all "acquisitions" are "labored" — is never truly learnt by Jude, though the narrator insistently foregrounds it for the reader. ${ }^{\text {xiv }}$ As Jonathan Memel has shown, Hardy's Jude has been an abiding touchstone in modern debates about class and education in Britain, his name invoked to convey the pathos of the bright working-class boy denied opportunity. Yet this cultural myth of Jude falsifies the novel in crucial respects. The novel is actually an attack on the archetype of the poor boy of promise, the exceptional child who is entitled to climb the scholarship ladder from obscurity to the "paradise of the learned" (113). Critics routinely characterise Jude as "bright", "talented" or "intelligent", but the narrator never passes judgment on Jude's mental ability and no other character in the novel credits him with particular intellectual gifts; Sue believes he ought to be admitted to Oxford on the grounds of his "passion for learning" (151), not because of any kind of innate intelligence. ${ }^{\mathrm{xv}}$ Jude himself doubts that has sufficient "brillian[ce]" and "natural ability" to win a scholarship (115). In Tess of the d'Urbervilles (1891), Hardy freely availed himself of contemporary discourses of innate intelligence to vindicate the worth of his heroine; the fact that he refrains from doing the same for Jude is 
important. ${ }^{\text {xvi }}$ After all, if Jude were presented as an unequivocally gifted young man, this would presumably serve to intensify the sense of injustice that attaches to his exclusion from university. Instead, however, the novel is a thornier provocation: it is the tragedy of an unexceptional poor boy who desperately wants to go to Oxford; more, it is the tragedy of a poor boy who becomes obsessed with the dream of Oxford precisely because he does not believe he has the "brains" to go.

In a review of Jude, Edmund Gosse derided Hardy’s apparent implication that Jude had to right to an Oxford fellowship and diagnosed Jude with "degeneracy" and "megalomania", although he is also decided that Jude showed "brightness" and might have "become fairly distinguished as a scholar" (64-65). Gosse's review illuminates the extent to which medical and pedagogical judgments had begun to shade into one another at the fin de siècle. Gosse responds to the novel as if it were a kind of psychometric test, inviting us to scrutinise Jude's mental fitness and thereby determine his eligibility for a scholarship. As Shuman has suggested, nineteenth century novelists were often self-conscious about the analogy between the realist novel and the examination: both forms purported to make nebulous mental qualities available for just evaluation (88-89). Although modern readers tend to appraise Jude more sympathetically than Gosse does, they nevertheless often share his impulse to assess Jude's worth as a university candidate. ${ }^{\text {xvii }}$ The novel's intervention in the late Victorian politics of education is both more radical and more ambiguous than such readings register. Jude is kind of anti-scholarship examination, laying bare all social and psychological forces which conspire to make Jude's latent intellectual capacities unknowable and his desire to go to Oxford utterly masochistic. In this, Hardy's contests the idea that the "natural ability" of a poor boy like Jude is discoverable, whether by competitive examination, social judgment, or even by the omniscience of a realist novelist. As I have argued elsewhere in relation to Henry James's The Tragic Muse (1890), such narratorial agnosticism about the 
intellectual gifts of a bildung protagonist ought to be understood as an attempt to resist the contemporary impetus to assess and measure intelligence (Lyons).

Jude highlights the extent to which the sentimental myth of the poor boy of talent was a subset of the larger political distinction between the deserving and undeserving poor. This distinction, concretised in Victorian culture by the New Poor Law of 1834 and implicit in much Victorian philanthropy, divided the poor into innocent victims entitled to charity and malefactors who required moral discipline or were simply beyond redemption (Romano 1329). As Gosse confused assessment of Jude's mental worth registers, his character is precisely constructed to confound this distinction. To a marked degree, Jude is the delinquent twin of the deserving scholarship boy: not only does he lack the requisite "brilliance", he drinks too much, cannot contain his sexuality, and is given to bouts of iconoclastic rage. He also shows symptoms of hereditary degeneracy, though as in Tess, heredity is treated more as a matter of folk superstition and class prejudice than of natural law in Jude. ${ }^{\text {xiii }}$ On the other hand, Jude is a paragon of the "respectable" poor insofar as he embodies the earnest commitment to hard work associated with Samuel Smiles and the mid-Victorian culture of self-help. However, Hardy ensures that Jude's commitment to his ambition registers not as virtuous Smilesian persistence but as a disturbing form of perseveration: in effect, Jude compulsively re-enacts the childhood trauma of his encounter with the grammar book and the annihilating self-hatred it induced. For this reason, the novel has been rightly understood as an indictment of the Smilesian model of social mobility, with the case of Jude demonstrating that no amount of individual striving suffices to overcome systemic oppression. ${ }^{\text {xix }}$ Yet it is more accurate to say that the novel captures how the mid-Victorian model of self-help could produce a devastating kind of cognitive dissonance when it became entangled with fin de siècle scientific determinism about intelligence. Despite their obvious incompatibility, Jude is the victim of both ideologies, afflicted on the one hand by the egalitarian promise of agency 
and moral reward held out by the Smilesian ideal and by the sense of fatalism purveyed by late Victorian discourses about heredity and brains.

As Simon Szreter notes, the late Victorian "scholarship ladder" was "an almost spectral tokenism"; in 1900, fewer than one in a thousand elementary school children were given assistance to attend the grade schools which could make university entry feasible (165). Nonetheless, Jude attests to the capacity of such fugitive meritocratic opportunity to possess the imagination. It is also attests to the ambiguous political implications of the scholarship ladder: while it could be understood as a democratic extension of educational opportunity, it could also convey the idea that mental ability is extremely rare among the poor. The Taunton Commissioners (1864-7) who were charged with reforming the grammar school system sought to create a scholarship competition that would identify "boys of exceptional talent" by "natural selection", as if exam performance were a proxy for evolutionary fitness. The Bryce Commission, an 1895 inquiry into secondary education in England, similarly recommended that scholarships be awarded to impoverished "boys of rare capacity" (Qtd. Wooldridge, 173174). Where in Tess Hardy finesses the distinction between the exceptional and the ordinary in order to aggrandise and universalise his heroine's tragedy by turns, in Jude, there is a more leaden emphasis upon the hero's ordinariness. As Emily Steinlight observes, Jude is always glimpsing himself "in the mirror of statistics" (228): he is dispirited by the thought that there are "thousands of young men on the same self-seeking track" (129) as himself. Interestingly, Sue, who does not conflate intellectual self-worth and social distinction as Jude does, is nonetheless haunted by the same sense that she is nothing special: she can take no pleasure in being considered "a clever girl" because "there are too many of that sort now" (107). This consciousness of one's statistical mediocrity, of there being "too many" other people of the same average type as oneself, lies at the core of the novel's tragedy. Steinlight focusses primarily on the Malthusian dimensions of the novel's statistical thinking, grimly captured in 
Father Time's suicide note: "done because we are too menny" (336). But the problem of "too menny" is not just a matter of overpopulation and the supposedly excessive fertility of the poor. It is an effect of mass education and the logic of the scholarship ladder. As is often noted, education can be conceptualised as a positional or competitive good; that is, it is a good whose value depends on its social distribution (Howell 2011, 19). As Jude's fantasies of Christminster make vivid, university education derived its quasi-sacral, quasi-aristocratic mystique in the Victorian age from its relative social scarcity. Toward the end of the novel, Jude laments that he could not benefit from new schemes to render university less "exclusive" (399), but the exclusivity of Oxford is the essence of its attraction for him. Indeed, increased social mobility and mass education pose a threat to Jude's fantasy life, crowding it with a horde of anonymous men with the same aspirations: "He sometimes felt that by caring for books he was not escaping common-place nor gaining rare ideas, every working-man being of that taste now" (66). Although Jude espouses “equality of opportunity" (304), he does not in fact want a more egalitarian education system, but to enjoy the sense of spiritual "election" possible within the existing elitist one (113). At the same time, Jude has no faith that he is exceptional. As he feels keenly, it is not enough that he be extremely diligent or passionate about books; in order to be a poor boy deemed worthy of Oxford, he must be a statistical and biological outlier, in possession of rare "natural ability". Jude's ambition is thus perfectly self-defeating, or a form of cruel optimism, in Lauren Berlant's influential formulation (1-22). It is not simply that he has an unrealistic dream of attending an elite institution; his own exclusion is constitutive of what he desires, insofar as the glamour of Oxford inheres in the fact that it is a "castle manned by scholarship and religion" (26) against the "too menny", the democratic mass from which he has no means of distinguishing himself.

Jude falls in love with Sue because she appears to incarnate and thereby to resolve his 
contradictory intellectual ideals. Firstly, he fancies that she embodies the kind of "disinterested", "ethereal" brilliance that he identifies with Oxford (187). Indeed, he imagines her intelligence just as he imagines the university, as a radiant fact of nature: he says that her intellect "scintillates like a star" (342) or plays like "lambent lightning" (344) (this is a perception of Sue shared by Jude's rival, the school teacher Mr. Phillotson: he remarks that Sue's intellect "sparkles like diamonds, while mine smoulders like brown paper" (229)). Secondly, Sue is also the meritocratic success story that Jude is not, even if her aspirations are more modest than his: she expects to "pass high" (133) in her examinations and duly wins a Queen's scholarship to attend teacher training college. Third, where Jude seems to experience only the alienation and "plodding" of autodidacticism, Sue exemplifies what an intellect can achieve by working outside of "ordained lines" (115): when Jude first encounters her, he is startled by her intellectual audacity, and she introduces him to the possibility that education might be experienced not as religious transcendence but as a pagan pleasure and liberation, an idea captured in her penchant for quoting A. C. Swinburne's poetry (150). Sue seems empowered by her very oppression: her gender means she is not prey to same illusions about Oxford as Jude, and her mind is thus freer to "play" among "conventions and formalities" (344). In contrast to him, she flippantly asserts her own mastery of Latin and Greek grammar and her wide reading of classical authors in translation, announcing that she has no "fear of men as such, nor of their books" (147). If Jude suggests the extent to which the autodidactic intellect may be stultified by a sense of inferiority, then Sue at least initially seems to exemplify what an emancipated intellect might look like: in Rancière's terms, she suggests "what an intelligence can do when it considers itself equal to any other and considers any other equal to itself" (Ignorant Schoolmaster 39).

Hardy's representation of Sue's intelligence condenses the same political ambiguities as his depiction of Jude's insofar as it we are invited to interpret it by turns as a product of 
education and as an effect of biological determinism. On the one hand, the narrative highlights that Sue's intellectualism is impressive because it is largely her own creation: it is a product of her adventurous reading programme, which has in turn fed her "Voltairean" (152) scepticism in the face of social orthodoxies. To this extent, Sue's intellect is her "advanced" theories, her feminism and atheism (166). On the other, Sue's intellect is biologised insofar as she is persistently characterised as neurasthenic. Both before and after the calamity of her children's deaths she is defined by her "tight-strained nerves" (110), and this pathologising discourse has multiple significations. Neurasthenia, or nervous exhaustion, was considered a typically feminine malady and sometimes linked specifically to the cultural stereotype of New Woman, particularly in her incarnation as the "exam girl" who had depleted her mental capacities through excessive "cramming" (Greenslade 135-137). But neurasthenia also carried a distinct intellectual prestige insofar as it was understood as an illness of modernity and a mark of high intelligence. The Romantic identification of madness with creative genius gained scientific authority at the fin de siècle, with a flurry of books claiming that modern brain science confirmed the poetic archetype. ${ }^{\mathrm{xx}}$ Whether the novel's emphasis upon Sue's "nerves" amounts to a sexist denigration of her intellect or serves to lend her some of the quasi-medical glamour of fin de siècle genius is open to dispute: Hardy's construction of her readily evokes both clichés. Hardy also leaves open the question of whether Sue's neurasthenia is a cause or effect of her intellectual rebelliousness, and thus the question of whether the pathology resides primarily in her or in the social order she rebels against. However, it is Sue's gender, or rather her departure from the norms of her gender, that inspires the novel's most categorical affirmation of biological determinism. It appears when the narrator describes the other women at Sue's teacher training college:

[...] they all lay in their cubicles, their tender feminine faces upturned [...] down the 
long dormitories, every face bearing the legend 'The Weaker' upon it, as the penalty of the sex wherein they were moulded, which by no possible exertion of their willing hearts and abilities could be made strong while the inexorable laws of nature remain what they are $[\ldots]$ Amid the storms and strains of after-years, with their injustice, loneliness, child-bearing and bereavement, their minds would revert to this experience as to something which had been allowed to slip past them insufficiently regarded.

It is significant that Hardy invokes the "inexorable laws of nature" in relation to a group of trainee teachers: is the hopes these women have invested in the transformative power of education that makes the biological limits of their "abilities" so pathetically stark. The pathos of their bondage is somewhat crudely amplified by the narrator's abrupt prolepsis: their education will be ineffectual, a faintly felt interlude in lives made predictable and homogeneous by biology. Yet part of the purpose of this passage is to highlight the rebellious individualism of Sue, who has escaped from the dormitory to visit Jude and, the narrator implies, is simultaneously attempting to escape from her biological destiny. If Sue does not in fact manage to avoid the stock fate of women, the text never attributes this to any weakness of her mental abilities; Jude's sense of awe at Sue's intellect, even in its ruined state, is never contradicted or undercut by the narrator.

The character of Arabella Donn is the most fraught expression of the novel's ambivalence toward the late Victorian biopolitics of mental capacity. Superficially, she is a grotesque manifestation of the Social Darwinist model of intelligence: a pig farmer's daughter who is herself depicted as bestial throughout the novel, her "clever[ness]" (401) is all animal instinct and ruthless self-interest. At the level of plot, Arabella is the principle of plebeian carnality which continually disrupts Jude's bildungsroman and spoils his rarefied 
ideals, whether she is hurling a pig's penis at him by way of seduction or wiping lard on his books. Within the terms of the novel's bleak transvaluation of Social Darwinism, Arabella is unredeemable because of her resilience and joie de vivre; as epitomised by her callousness in the wake of Jude's death, the will to survive and be happy can only come at the price of one's humanity in the moral universe of this novel. By the same logic, Jude's and Sue's despair of life proves that they are Arabella's moral and intellectual superiors: their failure to flourish in the world — what Galton or Maudsley would identify as their "degeneracy" — confirms their finer humanity, their shared status as beautiful souls. Yet this reading overlooks the extent to which the novel is of Arabella's party. Arabella's contempt for Jude's "higher" aspirations accords with the novel's wider attack on economic and educational inequality. In her unashamed vulgarity, Arabella actually lives out Jude and Sue's radical political ideals: she demonstrates the indifference to religion, sexual propriety, and class distinctions that they associate with enlightenment. More, she enacts the hedonistic naturalism that Sue can only theorise and yearn for: "Nature's intention, Nature's law and raison d'être [is] that we should be joyful in what instincts she afforded us" (33). Readers who experience an "illicit" sympathy with Arabella are not reading against the grain of the novel, but registering the extent to which she is allied with its politics, specifically its desire to vindicate the claims of the poor and the material realities of the body. ${ }^{\mathrm{xxi}}$

Hardy's critique of late Victorian hierarchies of the mind is distilled in the graffiti that Jude scrawls in chalk on a wall in Oxford, a quotation from the Book of Job: "I have understanding as well as you; I am not inferior to you: yea, who knoweth not such things as these?" ([Job 12.3],118). Jude is reacting to a patronising rebuff from the "Master of Biblioll College" and the walls of Oxford at this moment symbolise the impassable barriers to his intellectual aspirations (117). The fact that Jude derives his assertion of the equality of human intelligence from the Book of Job is rich with significance. The Book of Job has often been 
understood as the subversive book of the Hebrew Bible: Job's despairing interrogation of the nature of God's justice is open to being read as an archetype of religious doubt or political insubordination. ${ }^{\text {xxii }}$ Jude clearly invokes Job as a Biblical exemplar of a type of despair which radicalises the intellect and arouses righteous protest; in effect, he is countering the Oxford conflation of learning, religion, and privilege with his own identification of intellectual value with scepticism and suffering. However, the choice of quotation simultaneously undercuts the suggestion that suffering produces special insight. Jude's wisdom, like Job's, is both the privilege of his victimhood and banal, anybody's knowledge: "who knoweth not such things as these?" In this way, Jude grounds intellectual value in tragic suffering while also emphasising tragedy’s egalitarianism. ${ }^{\text {xxiii }}$ The fact that Jude finds authorisation for his act of iconoclasm in the Bible means that the graffiti also resonates as a pithy immanent critique of Oxford, which, as a Christian institution, purported to recognise the spiritual claims of the poor and outcast. In context, Jude's appropriation of Job's question accuses Oxford of possessing no recondite wisdom, of being founded upon the banality of social inequality — a truth that can be discerned as readily from outside its walls as from within them.

\section{Conclusion}

Adrian Wooldridge remarks that the idea of natural equality or any "root-and-branch egalitarianism" was marginalised for almost a century after the publication of Darwin's On the Origin of Species" (Wooldridge 2006, 295). As has been noted, around the turn of the century it became a cliché for scientists and intellectuals to denounce the stupidity of the doctrine of natural equality, particularly the notion that "men are born with equal original mental capacity" (Maudsley, 43). Yet the fact that it was necessary to debunk the idea 
suggests its persistent cultural vitality. Science had apparently made human equality unthinkable in the same decades that the Third Reform Act (1884), the birth of state education, and growth of the socialist movement incited people to think it: indeed, it was because Huxley believed that the ideal of "natural equality" was working "sad mischief" in the present that he felt compelled to attack the legacy of Jean-Jacques Rousseau (4).

When Rancière recuperates the idea of the equality of intelligence from the Rousseauist Jacotot, he constructs it not as a sober thesis for which he can supply evidence but as a kind of dare or wager, an invitation to an intellectual "adventure" upon which we ought to "gamble all [our] credibility" (Ignorant Schoolmaster 27, 68). He writes:

the problem isn't proving that all intelligence is equal. It's seeing what can be done under that supposition. And for this, it is enough that the opinion be possible - that is, that no opposing truth be proved. (Ignorant Schoolmaster 46).

In one sense, the notion of the equality of human intelligence has only a marginal or tragic life in Hardy's final novels: it is a critique placed in the mouth of Grammer Oliver in The Woodlanders or a Bible quote graffitied on a wall in Jude. Yet in another, the principle is ubiquitous: at every turn, these novels are efforts to count the uncounted intelligences of servants, agricultural laborers, pig farmer's daughters, Swinburne-quoting pupil-teachers and autodidact stonemasons. As Rancière emphasises, this is not a matter of idealising manual labor or the wisdom of the poor, but of annulling the distinction between elite and common minds, and making it impossible to imagine that there are people "really made for higher things" and people only made for "dumb suffering". 
Allen, Ansgar. Benign Violence: Education in and Beyond the Age of Reason. Basingstoke: Palgrave Macmillan, 2014.

Beer, Gillian. Darwin's Plots: Evolutionary Narrative in Darwin, George Eliot, and Thomas Hardy. Cambridge: Cambridge University Press, 2000.

Berlant, Lauren. Cruel Optimism. Duke University Press, 2011.

Birch, Dinah. Ed. The Oxford Companion to English Literature. $7^{\text {th }}$ Edition. Oxford: Oxford University Press, 2009.

Bownas, Jane L. Thomas Hardy and Empire: The Representation of Imperial Themes in the Work of Thomas Hardy. London: Routledge, 2016.

Carson, John. The Measure of Merit: Talents, Intelligence, and Inequality in the French and American Republics, 1750-1940. Princeton University Press, 2007.

Cohen, William. “Arborealities: The Tactile Ecology of Hardy's Woodlanders". 19: Interdisciplinary Studies in the Long Nineteenth Century 19 (2014): 1-22. https://www.19.bbk.ac.uk/articles/10.16995/ntn.690/

Cooper, Andrew. "Voicing the Language of Literature: Jude's Obscured Labor". Victorian Literature and Culture 28. 2 (2000): 391-410.

Danziger, Kurt. Naming the Mind: How Psychology Found its Language. London: Sage, 1997.

Darwin, Charles. The Descent of Man, and Selection in Relation to Sex. Ed. James Moore and Adrian Desmond. London: Penguin, 2004.

Daston, Lorraine. “The Naturalized Female Intellect”. Science in Context 5.2 (1992): 209235.

Dell, Katherine Julia. The Book of Job as Sceptical Literature. Berlin: Walter de Gruyter, 1991.

Dickey, Colin. Cranioklepty: Grave Robbing and the Search for Genius. CO: 
Unbridled Books, 2010.

Dutta, Shanta. Ambivalence in Hardy: A Study of His Attitude to Women. Basingstoke: Macmillan, 2000.

Eagleton, Terry. Sweet Violence: The Idea of the Tragic. Oxford: John Wiley \& Sons, 2009. Foucault, Michel. The History of Sexuality. Vol 1: An Introduction. Trans. Robert Hurley. London: Penguin Books, 1976.

Foucault, Michel. Society Must be Defended: Lectures at the College de France, 1975-76. Trans. David Macey. London: Penguin, 1997.

Frederickson, Kathleen. The Ploy of Instinct: Victorian Sciences of Nature and Sexuality in Liberal Governance. Fordham University Press, 2014.

Galton, Francis. Hereditary Genius. London: Macmillan, 1869.

Garber, Marjorie. Hardy's Fables of Integrity: Woman, Body, Text. Oxford: OUP, 1991.

Goodman, Lesley. "Rebellious Identification, or, How I Learned to Stop Worrying and Love Arabella". Narrative 18.2 (2010): 163-177.

Gosse, Edmund. “Mr. Hardy’s New Novel”. Cosmopolis (1896): 60-69.

Gould, Stephen Jay. The Mismeasure of Man. New York: W. W. Norton \& Company, 2006.

Greenslade, William. Degeneration, Culture, and the Novel. Oxford: Oxford University Press, 1994.

Hardy, Thomas. The Woodlanders. Ed. Dale Kramer. Oxford: Oxford University Press, 1981.

Hardy, Thomas. A Pair of Blue Eyes. Ed. Alan Manford. Oxford: Oxford University Press, 1985.

Hardy, Thomas. Tess of the d'Urbervilles. Ed. John Paul Riquelme. Boston: Bedford St. Martin’s, 1998.

Hardy, Thomas. Jude the Obscure. Ed. Dennis Taylor. Oxford: Oxford University Press, 1998. 
Heaney, John. “Arthur Schopenhauer, Evolution, and Ecology in Thomas Hardy's The Woodlanders". Nineteenth Century Literature 71.4 (2017): 516-545.

Howell, Charles. “Education as Positional Good Reconsidered”. Jpse 1 (2011): 19-36.

Huxley, T. H. “On the Natural Inequality of Men”. The Nineteenth Century 27 (1890): 1-23.

Ingham, Patricia. The Language of Gender and Class: Transformation in the Victorian Novel. London: Routledge, 1996.

Jackson, Mark. The Borderland of Imbecility: Medicine, Society, and the Fabrication of the Feeble Mind in Late Victorian and Edwardian England. Manchester: Manchester University Press, 2000.

Jacobus, Mary. "Tree and Machine: The Woodlanders". Critical Approaches to the Fiction of Thomas Hardy. Ed. Dale Kramer, 1979. 116-134.

Keen, Suzanne. Thomas Hardy's Brains: Psychology, Neurology, and Hardy's Imagination. University of Ohio Press, 2014.

Kevles, Daniel J. In the Name of Eugenics: Genetics and the Uses of Human Heredity. University of California Press, 1985.

Kidd, Benjamin. Social Evolution. London: Macmillan, 1894.

Kornbluh, Anna. "Obscure Forms: The Letter, the Law, and the Line in Hardy’s Social Geometry". Novel: A Forum on Fiction 48.1 (2015): 1-17.

Lilly, W. S. "Darwinism and Democracy". Fortnightly Review (1886): 34-50.

Lyons, Sara. “'You Must be as Clever as We Think You': Assessing Intelligence in Henry James’s The Tragic Muse”. Modern Philology 115.1 (2017): 105-130.

Marroni, Francesco. Victorian Disharmonies: A Reconsideration of Nineteenth-Century English Fiction. University of Delaware Press, 2010.

Mattisson, Jane. Knowledge and Survival in the Novels of Thomas Hardy. Lund University Press, 2002. 
Maudsley, Henry. Body and Mind. New York: D. Appleton \& Co., 1871.

Mazumdar, Pauline. Eugenics, Human Genetics, and Human Failings: The Eugenics Society, Its Sources and Its Critics in Britain. London: Routledge, 1991.

Memel, Jonathan. "“"Making the University Less Exclusive”: The Legacy of Jude the Obscure”. Neo-Victorian Studies 10.1, 2017.

Meroni, Maurizio. Political Biology: Science and Social Values in Human Heredity from Eugenics to Epigenetics. Basingstoke: Palgrave Macmillan, 2016.

Mill, John Stuart. On Liberty and Other Essays. Ed. John Gray. Oxford: Oxford University Press, 1991.

Morton, Peter. The Vital Science: Biology and the Literary Imagination 1860-1900. London: George Allen \& Unwin, 1984.

Orel, Harold. (Ed.) Thomas Hardy's Personal Writings. London: Macmillan, 1967.

Paul, Diane and Day, Benjamin. "John Stuart Mill, Innate Differences, and the Regulation of Reproduction”. Stud. Hist. Phil. Biol. \& Biomed. Sci. 39 (2008): 222-231.

Pearson, Karl. “Socialism and Natural Selection”. Fortnightly Review 56 (1894): 1-21.

Privateer, Michael Paul. Inventing Intelligence: A Social History of Smart. Oxford: Blackwell, 2006.

Rancière, Jacques. Mute Speech: Literature, Critical Theory, and Politics. Trans. James Swenson. New York University Press, 1998.

Rancière, Jacques. The Ignorant Schoolmaster: Five Lessons in Intellectual Emancipation. Trans. Kristin Ross. Stanford University Press, 1991.

Rancière, Jacques. The Flesh of Words: The Politics of Writing. Trans. Charlotte Mandell. Stanford University Press, 2004.

Rancière, Jacques. Aesthetics and its Discontents. Trans. Stephen Corcoran. Cambridge: Polity Press, 2009. 
Rancière, Jacques. Chronicles of Consensual Times. Trans. Stephen Corcoran. London: Continuum, 2010.

Rancière, Jacques. The Politics of Literature. Trans. Julie Rose. Cambridge: Polity Press, 2011.

Rancière, Jacques. Dissensus: On Politics and Aesthetics. Trans. Stephen Corcoran. London: Bloomsbury, 2015.

Rancière, Jacques. The Lost Thread: The Democracy of Modern Fiction. Trans. Steven Corcoran. London: Bloomsbury, 2017.

Reid, Fred. Thomas Hardy and History. Basingstoke: Palgrave Macmillan, 2017.

Ribot, Théodule. Heredity: A Psychological Study of its Phenomena, Laws, Causes, and Consequences. London: Henry S. King \& Co., 1875.

Richardson, Angelique. "Hardy and Biology”. Ed. Philip Mallet. Thomas Hardy: Texts and Contexts. Basingstoke: Palgrave Macmillan, 2002.

Richardson, Angelique. Love and Eugenics in the Late Nineteenth Century: Rational Reproduction \& the New Woman. Oxford: Oxford University Press, 2003.

Ritchie D. G. "Equality”. Contemporary Review 62 (1892): 563-568.

Roach, John. Public Examinations in England 1850-1900. Cambridge: Cambridge University Press, 1971.

Romano, Serena. Moralising Poverty: The 'Undeserving' Poor in the Public Gaze. London: Routledge, 2017.

Shuman, Cathy. Pedagogical Economies: The Examination and the Victorian Literary Man. Stanford University Press, 2000.

Shuttleworth, Sally. The Mind of the Child: Child Development in Literature, Science, and Medicine 1840-1900. Oxford: Oxford University Press, 2013.

Spencer, Herbert. The Principles of Biology. Vol 1. London: Williams and Norgate, 1864. 
Spencer, Herbert. The Principles of Psychology. Vol 1. $3^{\text {rd }}$ Edition. London: Williams and Norgate, 1890.

Steinlight, Emily. "Hardy's Unnecessary Lives: The Novel as Surplus". Novel: A Forum on Fiction 47.2 (2014): 224-241.

Stiles, Anne. Popular Fiction and Brain Science in the Late Nineteenth Century. Cambridge: Cambridge University Press, 2011.

Sutherland, Gillian. Ability, Merit, and Measurement: Mental Testing and English Education 1880-1940, Oxford: Clarendon Press, 1984.

Szreter, Simon. Fertility, Class, and Gender in Britain, 1860-1940. Cambridge: Cambridge University Press, 2002.

Venn, John. "Cambridge Anthropometry". Journal of the Anthropological Institute 18 (1889): 140-154.

Wells, H. G. Anticipations of the Reaction of Mechanical and Scientific Progress upon Human Life and Thought. London: Chapman \& Hill, 1901.

White, Paul. "Acquired Character: The Hereditary Material of the Self-Made Man". Heredity Produced: At the Crossroads of Biology, Politics, and Culture 1500-1870. Ed. Staffan Müller-Wille and Hans-Jörg Rheinberger. MIT Press, 2007.

Wilson, Andrew. "The Old Phrenology and the New". The Gentleman's Magazine 244 (1879): 68-85.

Woloch, Alex. The One vs. the Many: Minor Characters and the Space of the Protagonist in the Novel. Princeton University Press, 2003.

Wooldridge, Adrian. Measuring the Mind: Education and Psychology in England c.18601990. Cambridge: Cambridge University Press, 2006.

Sara Lyons, Senior Lecturer in Victorian Literature, University of Kent 
i Beer identifies "the problem of finding a scale for the human" in relation to Darwinian evolution as the "besetting preoccupation" of Hardy's work (233). On the rise of eugenics in late nineteenth-century Britain, see Kevles, Mazumdar, and Richardson 2003.

ii See Carson, Gould, Privateer, Sutherland, and Wooldridge.

iii For a detailed history of this process, see Roach.

iv See Darwin 2004, 46. I cite these psychologists because we know Hardy was familiar with their work; see Keen, 17-52. On the hereditary nature of intellectual ability, see Maudsley 1875, 43; Ribot 1875, 65-80; and Spencer 1864, 188-189.

${ }^{v}$ See for example Galton 1869, 14; Huxley; Kidd 1894, 184; Lilly; and Wells, 291 . Contemporary thinkers also remarked upon the fact that it had become routine to invoke science in order to contest the principle of equality. See Ritchie and Pearson.

${ }^{\mathrm{vi}}$ For the strongest articulation of the case, see Morton, 194-211; for a more recent version of this argument, see Shuttleworth, 335-352. Keen provides a useful map of Hardy's reading of contemporary science and psychology (17-52).

vii Steinlight has already shown the value of Rancière's work for interpreting Hardy, and my own discussion of Jude is indebted to her ground-breaking reading.

viii Galton first attempts to delineate the distinction between "nature" and "nurture" in English Men of Science: Their Nature and their Nurture (1874). Initially a heuristic distinction even for him, the phrase rapidly comes to imply both in his work and in the wider culture that "nature" and "nurture" represent "separate ontological realms" (Meroni, 43).

${ }^{i x}$ For a rich account of how the distinction between reason and instinct became unstable over the course of the nineteenth century, see Frederickson.

${ }^{x}$ See especially the often-quoted passage which emphasises the violence of the struggle for existence among trees (Woodlanders 48).

${ }^{x i}$ For analysis of the biologisation of poverty and crime in the 1890s, see Richardson 2003, 13-31; on the emergence of the category of "feeble-mindedness", see Jackson, 23-54.

xii This phrase is Kornbluh's, though she discusses the novel's biopolitical imagination only in passing (2). Like Steinlight, she is thinking primarily of the novel's apparent complicity with the Malthusian logic of Father Time's suicide note.

xiii Shuttleworth reads Jude's tragedy the light of Victorian psychiatry and hereditarian discourses (335-352).

xiv See Cooper for a detailed account for how Hardy's narrator clarifies the oppressive effects of Jude's tendency to devalue his own labor.

${ }^{\mathrm{xv}}$ For instance, the Oxford Companion to English Literature characterises Jude as a young villager of "exceptional intellectual promise"; see Birch, 544. Mattisson refers to his "obvious talents" and "intelligence" (274), while Richardson suggests he is "far more gifted naturally than the men who are born to privilege" $(2002,171)$. Memel also shows how frequently the novel has been read as a "the first great literary treatment of the idea that talent can be wasted by exclusion from university", in the words of Boris Johnson (4).

xvi The narrator of Tess continually insists that Tess Durbeyfield is "clever", has "naturally quickness' (185), a "rar[e] intelligence' or a "naturally bright intelligence” (210). xvii See Memel.

xviii For analysis of the ambiguous and ironic dimensions of Hardy's use of degeneration theory in Jude, see Steinlight, 229-231.

xix See Ingham, 170-174.

${ }^{\mathrm{xx}}$ See Stiles, 126-133. 
xxi On Arabella as an object of "illicit" readerly identification, see Goodman. xxii See Dell.

xxiii Eagleton observes that the aristocratic genre of tragedy is democratised in modern literature: the "jealously patrolled frontiers between tragic registers and non-tragic victims" break down and anyone can be a tragic subject (95). 